\title{
A behavioral-genetic investigation of bulimia nervosa and its relationship with alcohol use disorder
}

\author{
Sara Elizabeth Trace $^{\mathrm{a}}$, Laura Marie Thornton ${ }^{\mathrm{a}}$, Jessica Helen Baker ${ }^{\mathrm{a}}$, Tammy Lynn Root ${ }^{\mathrm{a}}$, \\ Lauren Elizabeth Janson $^{\mathrm{a}}$, Paul Lichtenstein ${ }^{\mathrm{b}}$, Nancy Lee Pedersen ${ }^{\mathrm{b}, \mathrm{c}}$, and Cynthia Marie \\ Bulik $^{\mathrm{a}, \mathrm{d},{ }^{*}}$ \\ aDepartment of Psychiatry, University of North Carolina, Chapel Hill, NC, USA \\ ${ }^{b}$ Department of Medical Epidemiology, Karolinska Institutet, Stockholm, Sweden \\ 'Department of Psychology, University of Southern California, Los Angeles, CA, USA \\ dDepartment of Nutrition, University of North Carolina, Chapel Hill, NC, USA
}

\begin{abstract}
Bulimia nervosa (BN) and alcohol use disorder (AUD) frequently co-occur and may share genetic factors; however, the nature of their association is not fully understood. We assessed the extent to which the same genetic and environmental factors contribute to liability to BN and AUD. A bivariate structural equation model using a Cholesky decomposition was fit to data from 7,241 women who participated in the Swedish Twin study of Adults: Genes and Environment. The proportion of variance accounted for by genetic and environmental factors for BN and AUD and the genetic and environmental correlations between these disorders were estimated. In the bestfitting model, the heritability estimates were 0.55 (95\% CI: 0.37 ; 0.70) for BN and 0.62 (95\% CI: $0.54 ; 0.70)$ for AUD. Unique environmental factors accounted for the remainder of variance for BN. The genetic correlation between BN and AUD was 0.23 (95\% CI: 0.01; 0.44), and the correlation between the unique environmental factors for the two disorders was 0.35 (95\% CI: $0.08 ; 0.61)$, suggesting moderate overlap in these factors. Findings from this investigation provide additional support that some of the same genetic factors may influence liability to both BN and AUD.
\end{abstract}

\section{Keywords}

bivariate; comorbidity; twin study

\section{Introduction}

Bulimia nervosa (BN) and alcohol use disorder (AUD; alcohol abuse/dependence) frequently co-occur (Bulik, 1987; Garfinkel et al., 1995; Bulik et al., 1997; Lilenfeld et al., 1998; Herzog et al., 1999; Dansky et al., 2000; Wade et al., 2004; Pereyra et al., 2010; Root et al., 2010). Estimates of the lifetime prevalence of AUD in women with BN have ranged

\footnotetext{
(C) 2013 Elsevier Ireland Ltd. All rights reserved.

"Correspondence to: Cynthia Marie Bulik, Department of Psychiatry, University of North Carolina at Chapel Hill, CB \#7160, 101 Manning Drive, Chapel Hill, NC 27599-7160, Voice: (919) 8431689 Fax: (919) 843 8802, cbulik@med.unc.edu..

Publisher's Disclaimer: This is a PDF file of an unedited manuscript that has been accepted for publication. As a service to our customers we are providing this early version of the manuscript. The manuscript will undergo copyediting, typesetting, and review of the resulting proof before it is published in its final citable form. Please note that during the production process errors may be discovered which could affect the content, and all legal disclaimers that apply to the journal pertain.
} 
from approximately 9\% (Pyle et al., 1981) to 49\% (Bulik, 1987), with the majority of investigations reporting between 20\% and 25\% (Mitchell et al.,1985; Holderness et al., 1994; Bulik et al., 2004; Baker et al., 2010; Root et al., 2010). Yet, the nature of this association is incompletely understood.

One compelling hypothesis is that BN and AUD may share a familial diathesis. Results from family studies have been inconsistent (Bulik, 1987; Kassett et al., 1989; Lilenfeld et al., 1997). For example, although studies uniformly reported that BN and AUD co-occurred in families, Lilenfeld et al. (1997) found that only BN probands with AUD had higher rates of AUD in family members, suggesting possible independent transmission of the disorders. One limitation of family studies is that they are unable to disaggregate genetic and common environmental effects. Twin studies, in contrast, allow the variance in liability to be partitioned into additive genetic (A; the cumulative impact of several genes of small to moderate effect), common environmental $(\mathrm{C}$; environmental effects that increase similarity in twins and result from etiological factors to which both members of a twin pair are exposed regardless of zygosity such as childhood socioeconomic status), and unique environmental factors (E; factors that make twins dissimilar; the $\mathrm{E}$ term also includes measurement error). Bivariate models can extend that paradigm to determine the extent to which these factors contribute to the liability of both disorders.

Two investigations using twin methodology have examined the genetic and environmental association between BN and AUD (Kendler et al., 1995; Baker et al., 2010). Kendler et al. (1995) applied multivariate pathway models to lifetime history of six major psychiatric disorders including $\mathrm{BN}$ and alcoholism. In the best-fitting model, a large proportion of the genetic liability to alcoholism was attributable to genetic factors that did not influence liability to the other five disorders; however, there was evidence of some overlap in genetic liability between BN and alcoholism (6\%, as reported by Slane et al., 2012).

In a second investigation using the same population-based sample from the Virginia Twin Registry (Kendler and Prescott, 2006), which included additional data from subsequent occasions of measurement, Baker et al. (2010) examined the genetic association between BN symptom count (i.e., a positive score was given for each BN symptom) and AUD. Using a bivariate approach, they reported a genetic correlation of 0.53 (95\% confidence interval (CI): $0.30 ; 0.80)$ in the best-fitting model, suggesting moderate overlap in genetic factors contributing to BN and AUD. However, the broad CI indicates a lack of statistical power to assess the strength of the association.

Another recent investigation (Slane et al., 2012) examined the nature of the association between individual bulimic behaviors (i.e., binge eating and the use of inappropriate compensatory behaviors such as self-induced vomiting or laxative use) and problematic alcohol use in a small sample $(n=292)$ of female twins from the Michigan State University Twin Registry (Klump and Burt, 2006). Parameter estimates for the best-fitting models indicated some overlap in genetic factors contributing to the liability of problematic alcohol use and binge eating (genetic correlation $=0.31$ (95\% CI: $0.09 ; 0.53)$ ) and also of problematic alcohol use and compensatory behaviors (genetic correlation $=0.61(95 \% \mathrm{CI}$ : $0.34 ; 1.00)$ ). These results provide additional evidence that some of the same genetic factors influence both bulimic behaviors and problematic alcohol use. However, the sample in this investigation was small, which might have decreased power and resulted in less precise estimates.

Thus, the results of these studies taken together suggest that BN and AUD may have shared genetic factors; however, additional large population-based twin studies of different samples are necessary to replicate and further elucidate the nature of this association. The purpose of 
this investigation was to evaluate the extent to which the same genetic and environmental factors contribute to the liability to both BN and AUD using a large population-based sample of twins from Sweden.

\section{Method}

\subsection{Participants}

Participants were from the Swedish Twin study of Adults: Genes and Environment (STAGE; http://ki.se/ki/jsp/polopoly.jsp?d=9610\&l=en), which is a subsample of the Swedish Twin Registry (STR; http://ki.se/ki/jsp/polopoly.jsp?d=9610\&l=en). STAGE is a population-based prospective sample of Swedish twins born 1959-1985. In 2005, twins aged 20-47 were asked about demographic characteristics, health, and life-style habits using webbased surveys with a telephone survey option. Over 25,000 individuals from a total sample of 43,000 participated (response rate $=59.6 \%$ ). A more detailed description of the study design can be found elsewhere (Lichtenstein et al., 2006; Furberg et al., 2008). STAGE was approved by the Regional Ethics Committee at Karolinska Institutet and by the Biomedical Institutional Review Board at the University of North Carolina at Chapel Hill. All participants provided informed consent through the web-based interview or the telephone interview.

Our final sample for twin modeling included 4,238 MZ women and 3,003 DZ women from same sex pairs: 1,816 MZ and 1,275 DZ pairs with complete data, $281 \mathrm{MZ}$ and $209 \mathrm{DZ}$ pairs with incomplete data, and $44 \mathrm{MZ}$ and $35 \mathrm{DZ}$ individuals without cotwin information. The mean age was 33.0 years $(S D=7.6)$.

\subsection{Zygosity}

Zygosity was assigned using responses from the following questions: (Q1) During childhood, were you and your twin partner as alike as 'two peas in a pod' or no more alike than siblings in general? and (Q2) How often did strangers have difficulty distinguishing between you and your twin partner when you were children? If both members of a twin pair responded 'alike as two peas in a pod' for Q1 and 'almost always' or 'often' for Q2, they were classified monozygotic (MZ). If both twins responded 'not alike' for Q1 and 'seldom,' 'almost never' or 'never' for Q2, they were classified dizygotic (DZ). All other twins were classified as 'not determined.' This algorithm was validated using a panel of 47 single nucleotide polymorphisms (SNPs) in 198 randomly chosen twin pairs (Lichtenstein et al., 2002). Ninety-five percent $(n=188)$ were correctly classified.

\subsection{Measures}

Information about lifetime eating disorders was collected using an assessment based on the Structured Clinical Interview (SCID) for Diagnostic and Statistical Manual of Mental Disorders-IV (DSM-IV; First et al., 1997), which assesses major Axis I psychiatric diagnoses according to DSM-IV (American Psychiatric Association, 2000) diagnostic criteria. The reliability and validity of the SCID have been well-demonstrated, although estimates have varied across studies (for review see First and Gibbon, 2004). The lifetime prevalence of $\mathrm{BN}$ in this sample was $1.18 \%$ for women, which is somewhat lower than estimates from other population-based samples (Wade et al., 2006; Hudson et al., 2007; Baker et al., 2010). To increase statistical power, we used a broader definition for BN. This decision was made based on increasing evidence that a binge eating frequency of approximately four times a month, rather than the current twice a week frequency criterion for BN, is the most empirically validated threshold (Sullivan et al., 1998; Trace et al., 2012). Further, a frequency criterion of four times per month has been suggested for DSM-5 (Wilson and Sysko, 2009) and is an anticipated modification. In addition, previous research 
using this sample showed that the heritability point estimates for the DSM-IV (American Psychiatric Association, 2000) definition of $\mathrm{BN}\left(\mathrm{a}^{2}=0.62 ; 95 \%\right.$ confidence interval (CI): $0.40,0.75)$ and a broader definition $\left(\mathrm{a}^{2}=0.61 ; 95 \% \mathrm{CI}: 0.46 ; 0.73\right)$ were approximately the same (Bulik et al., 2010). Therefore, BN was considered present if the participant: (1) responded yes to having had eating binges when they ate what most people would regard as an unusually large amount of food in a short period of time with at least slight loss of control; (2) indicated that s/he engaged in vomiting, exercised more than two hours per day, fasted, or used laxatives, diuretics, diet pills, or other methods during the same time that s/he was binge eating; (3) reported that binge eating occurred at least four times a month for at least three months; and (4) endorsed that weight or shape are moderately important things, important things, or the most important things that affect how she feel about herself. Participants were coded positive for $\mathrm{BN}$ if all criteria were present, negative for $\mathrm{BN}$ if only some criteria were met, and 'missing' if a diagnosis could not be made.

Lifetime alcohol abuse and dependence were also evaluated using an assessment based on the SCID for DSM-IV (First et al., 1997). This instrument assesses major Axis I psychiatric diagnoses according to DSM-IV (American Psychiatric Association, 2000) diagnostic criteria. All abuse and dependence criteria were assessed. If the participant met criteria for either abuse or dependence, she was coded positive for AUD. Participants were coded as missing if enough criteria were missing that a diagnosis could not be made. All others were coded as not meeting criteria for AUD.

\subsection{Statistical analyses}

2.4.1 Rationale-Biometric twin modeling is used in genetic epidemiology research to estimate the proportion of variance that genetic and environmental factors contribute to the liability to a latent phenotype. Specifically, these models assess the contribution of (1) additive genetic factors (heritability, $\left.\mathrm{a}^{2}\right)$; (2) common environmental factors $\left(\mathrm{c}^{2}\right)$; and (3) unique environmental factors and measurement error $\left(\mathrm{e}^{2}\right)$ to the liability to a phenotype such that the total variance is the sum of $\mathrm{a}^{2}+\mathrm{c}^{2}+\mathrm{e}^{2}$. Thus, by evaluating this 'ACE' model, the proportion of variance in liability to a disorder that is due to these genetic and environmental factors can be estimated. By comparing within-twin, cross-trait tetrachoric correlations for MZ twins with those for DZ twins, initial information regarding the genetic and environmental influences on liability to each of the two traits (BN and AUD) individually can be estimated. A similar comparison of the cross-twin, cross-trait tetrachoric correlations provides information on the shared liability between the traits (genetic and environmental correlations). This is because MZ twins share approximately $100 \%$ of their segregating genes and DZ twins share on average 50\%. Thus, a larger within-twin, cross-trait correlation for $\mathrm{MZ}$ twins compared with DZ twins indicates that genetic factors influence the latent phenotype. Likewise, a larger cross-twin, cross-trait correlation for MZ twins compared with DZ twins indicates that genetic factors contribute to the phenotypic association of the traits. The presence of shared environmental factors is evident when the cross-twin, cross-trait correlation for DZ twins is greater than twice that of the MZ twins. Under the equal environment assumption (EEA), common environmental influences are assumed to contribute equally to the correlation between members of MZ pairs and DZ pairs (Neale and Cardon, 1992).

2.4.2. Current study —A bivariate structural equation model using Cholesky's decomposition was fitted using the raw data option in Mx (Neale et al., 2001) statistical software to estimate $\mathrm{a}^{2}, \mathrm{c}^{2}$, and $\mathrm{e}^{2}$ for BN and AUD and to estimate correlations indicating the proportion of variance the two traits share due to genetic $\left(\mathrm{r}_{\mathrm{a}}\right)$, common environmental $\left(\mathrm{r}_{\mathrm{c}}\right)$, and unique environmental $\left(\mathrm{r}_{\mathrm{e}}\right)$ factors. For example, a genetic correlation estimated to be 1.00 indicates $100 \%$ overlap in the genetic factors influencing liability to the two traits. 
The raw data option in Mx (Neale et al., 2001) considers data to be missing at random: listwise deletion is not applied. Thus, if data for one twin in a pair are missing, information from the other twin is still retained. If data are missing at random, unbiased estimates should be obtained (Little and Rubin, 1987). The full model, which estimates all the genetic and environmental parameters for BN and AUD and all genetic and environmental correlations and controls for age, and seven nested models varying the parameters estimated were fit. Model selection was based on evaluating results from chi-square $\left(\chi^{2}\right)$ difference tests. The $\chi^{2}$ difference test assesses the difference in $-2 \operatorname{lnL}$ (minus twice the log likelihood) between the nested model and the full model, which is distributed as a $\chi^{2}$ where degrees of freedom (df) is equal to the difference between the df of the nested model and the full model (Neale and Cardon, 1992). A significant difference ( $\mathrm{p}<0.05)$ indicates that the model fits worse and should not be retained; a non-significant difference indicates no worsening of fit between the two models rendering the parsimonious model preferred. Model selection was also based on Akaike's Information Criteria [AIC] (Akaike, 1987): the lowest AIC value indicates the best-fitting model with regard to precision and complexity. We report both the best-fitting and full models but focus our discussion on the best-fitting model in order to compare our findings to the results of previous studies examining the overlap between BN and AUD, all of which do not report the full model. Parameter estimates and 95\% CI are presented.

\section{Results}

\subsection{Sample characteristics}

In our sample of 7241 women, the prevalence of the broad definition of BN was $2.21 \%$ and the prevalence of AUD was $6.86 \%$. Specifically, a total of 153 women met criteria for BN and 497 met criteria for AUD. Thirty women met criteria for both BN and AUD. No significant differences between $\mathrm{MZ}$ and DZ twins were observed for the prevalence of BN $\left(\chi^{2}=0.29, p<0.59\right)$ or AUD $\left(\chi^{2}=0.97, p<0.33\right)$.

\subsection{Twin models}

3.2.1. Bulimia nervosa and alcohol use disorder-Table 1 presents the tetrachoric correlation coefficients, $95 \% \mathrm{CI}$, and number of concordant pairs for each correlation for the bivariate models. Point estimates should be interpreted in the context of the 95\% CIs and number of concordant pairs. For both BN and AUD, the tetrachoric correlations for MZ twins were greater than those for DZ twins, indicating that genetic factors contribute to the liability to both disorders. The difference between MZ and DZ cross-twin, cross-trait tetrachoric correlations indicated that BN and AUD have some of these genetic factors in common.

Table 2 presents the full model (i.e., model I) and the nested models with varying parameters (models II-VIII) that were applied to the data. The $\chi^{2}$ difference tests indicate that models VII (all genetic parameters set to zero) and VIII (all genetic and common environmental parameters set to zero) could be rejected as fitting significantly worse than the full model ( $\mathrm{p}<0.05$ for all models). Of the remaining models, model IV (all common environmental parameters set to zero) was the best-fitting model as indicated by the lowest AIC value: additive genetic and unique environmental parameters and correlations were estimated for BN and AUD.

Table 3 presents the parameter estimates for the full and best-fitting models. For the full model, the correlation between additive genetic factors for BN and AUD was $r_{a}=0.31(95 \%$ CI: $-0.24 ; 1.00)$, and for unique environmental factors was $r_{e}=0.35$ (95\% CI: $\left.0.07 ; 0.60\right)$. In the best-fitting model, the additive genetic and unique environmental parameter estimates 
for BN were $\mathrm{a}^{2}=0.55$ (95\% CI: 0.37; 0.70) and $\mathrm{e}^{2}=0.45$ (95\% CI: $\left.0.30 ; 0.63\right)$. The additive genetic and unique environmental parameter estimates for AUD were $\mathrm{a}^{2}=0.62(95 \% \mathrm{CI}$ : $0.54 ; 0.70)$ and $\mathrm{e}^{2}=0.38(95 \% \mathrm{CI}: 0.30 ; 0.46)$. The correlation between the genetic factors was $r_{a}=0.23$ (95\% CI: $\left.0.01 ; 0.44\right)$ and for the unique environmental factors was $r_{e}=0.35$ (95\% CI: $0.08 ; 0.61)$. Approximately half of the within-twin phenotypic tetrachoric correlation of 0.28 was due to genetic and unique environmental factors, respectively (based on calculations from $\mathrm{r}_{\mathrm{p}}=\mathrm{a}_{\mathrm{BN}} * \mathrm{a}_{\mathrm{AUD}} * \mathrm{r}_{\mathrm{a}}+\mathrm{e}_{\mathrm{BN}} * \mathrm{e}_{\mathrm{AUD}} * \mathrm{r}_{\mathrm{e}}$ ).

\section{Discussion}

We replicated and extended previous findings from other twin investigations (Kendler et al., 1995; Baker et al., 2010; Slane et al., 2012) in a large population-based sample from Sweden. The best-fitting (AE-AE, $r_{a} r_{e}$ ) twin model suggests that BN is substantially heritable $\left(\mathrm{a}^{2}=0.55\right)$. This finding is consistent with the best-fitting model from Baker et al. (2010) $\left(\mathrm{a}^{2}=0.42\right)$ as well as with other univariate and bivariate twin studies reporting the heritability of BN (Kendler et al., 1991; Walters et al., 1992; Bulik et al., 1998; Kortegaard et al., 2001). Kendler et al. (1995) reported a lower heritability estimate for BN in their best fitting multivariate model $\left(\mathrm{a}^{2}=0.30\right)$ (no CIs presented); however, that estimate falls within the CI of the full, but not the best-fitting, model in the present investigation. For AUD, the best-fitting model also suggests substantial heritability $\left(\mathrm{a}^{2}=0.62\right)$. Both Baker et al. (2010) and Kendler et al. (1995) reported similar findings with heritability estimates from the bestfitting model for AUD of 0.53 and 0.59, respectively. Several other twin investigations of AUD have obtained similar estimates (Heath et al., 1997; Kendler et al., 2007; Sartor et al., 2011).

The genetic correlation for BN and AUD in the best-fitting model was estimated to be 0.23 ( $95 \%$ CI: $0.01 ; 0.44$ ), providing empirical evidence that some of the same genetic factors influence liability to both of these two disorders. The genetic correlation point estimate in this investigation is lower than that reported by Slane et al. (2012) for the association between problematic alcohol use and binge eating ( 0.31 in the best fitting model), and lower than the genetic correlation reported between problematic alcohol use and compensatory behaviors ( 0.61 in the best fitting model). The genetic correlation point estimate in the current investigation was also lower than that reported by Baker et al. $(2010 ; 0.53)$ in the best-fitting model. However, the CIs from all studies are wide and overlapping with the remaining common liability accounted for by unique environmental factors. In addition, the total percent of variance accounted for by shared genetic factors in our study was small (3\%), which is similar to that of Kendler et al. (1995) (6\% as reported by Slane et al., 2012).

One hypothesis regarding the nature of the genetic factors contributing to both BN and AUD is that these factors may confer risk for both disorders through common neuronal pathways. Food and alcohol seeking behaviors are both influenced by neurotransmitters implicated in reward including dopamine, glutamate, gamma-aminobutyric acid, and opioids (Volkow \& Wise, 2005; Blum et al., 2011). Abnormalities in these pathways may result in a phenotype marked by increased reward seeking behavior and impulsivity, which are frequently observed in both BN and AUD (Dawe and Loxton, 2004). Further, a growing literature suggests that appetitive peptides such as neuropetide $\mathrm{Y}$ and ghrelin may also be involved in AUD (Leggio et al., 2011). Neurotransmitters implicated in reward and appetite hormones may also act in concert (Morley, 1980; Brunetti et al., 2002), highlighting the complex nature of these interactions.

We also observed that approximately half of the phenotypic correlation between BN and AUD was due to unique environmental influences, or environmental influences that contribute to twin dissimilarity. This positive correlation differs from Baker et al. (2010) 
who reported a unique environmental correlation of -0.03 (95\% CI: $-0.24 ; 0.18)$ in the bestfitting model. Reasons for this inconsistency might include the use of different definitions for BN and AUD as well as interview versus self-report assessment measures.

Limitations to this study should be considered. First, this sample included only adult women from Sweden. Results might differ for men or for different ancestry and age groups. Second, these data were collected via computer-administered assessments. Although computeradministered self-report assessments may encourage participants to be more forthcoming with sensitive information, they may also be less precise than interview-based assessment methods (Tourangeau and Smith, 1998). Third, a broad definition of BN was used in this investigation, and our results must be confined to the symptom profile specifically described in this study. Fourth, given the nature of twin studies, causal conclusions regarding which specific genetic and/or unique environmental factors that may be involved in the association between BN and AUD cannot be determined.

This study provides additional empirical evidence that BN and AUD are influenced by some of the same genetic factors and also suggests that unique environmental factors may influence liability to both disorders. A more comprehensive understanding of factors predisposing and maintaining risk for BN and AUD is essential for developing novel treatment and prevention interventions targeting these pernicious and often comorbid disorders. Future investigations in large population-based samples may further elucidate factors that increase liability to both BN and AUD. At present, the frequent co-occurrence of these disorders and evidence of overlapping genetic factors underscore the importance of screening for BN and AUD in women presenting with either disorder.

\section{Acknowledgments}

Drs. Trace and Baker were supported by National Institute of Health grant T32MH076694 (PI: Bulik). Drs. Thornton and Root were supported by National Institute of Health grant 1K01AA 18719-01A1 (PI: Root). This study was also supported by grants CA-085739 (PI: Sullivan) and AI-056014 (PI: Sullivan) from the National Institutes of Health. The Swedish Twin Registry is supported by grants from the Swedish Department of Higher Education the Swedish Research Council. All authors reported no biomedical financial interests or potential conflicts of interest. We thank all participants for their time and efforts.

\section{References}

Akaike H. Factor analysis and AIC. Psychometrika. 1987; 52:317-332.

American Psychiatric Association. Diagnostic and Statistical Manual of Mental Disorders, $4^{\text {th }}$ ed. Text Revision.. American Psychiatric Press; Washington, D.C: 2000.

Baker JH, Mitchell KS, Neale MC, Kendler KS. Eating disorder symptomatology and substance use disorders: prevalence and shared risk in a population based twin sample. International Journal of Eating Disorders. 2010; 43:648-658. [PubMed: 20734312]

Blum K, Liu Y, Shriner R, Gold MS. Reward circuitry dopaminergic activation regulates food and drug craving behavior. Current Pharmaceutical Design. 2011; 17:1158-1167. [PubMed: 21492092]

Brunetti L, Recinella L, Orlando G, Michelotto B, Di Nisio C, Vacca M. Effects of ghrelin and amylin on dopamine, norepinephrine and serotonin release in the hypothalamus. European Journal of Pharmacology. 2002; 454:189-192. [PubMed: 12421646]

Bulik CM. Drug and alcohol abuse by bulimic women and their families. American Journal of Psychiatry. 1987; 144:1604-1606. [PubMed: 3688289]

Bulik CM, Klump KL, Thornton L, Kaplan AS, Devlin B, Fichter MM, Halmi KA, Strober M, Woodside DB, Crow S, Mitchell JE, Rotondo A, Mauri M, Cassano GB, Keel PK, Berrettini WH, Kaye WH. Alcohol use disorder comorbidity in eating disorders: a multicenter study. Journal of Clinical Psychiatry. 2004; 65:1000-1006. [PubMed: 15291691]

Bulik CM, Sullivan PF, Carter FA, Joyce PR. Lifetime comorbidity of alcohol dependence in women with bulimia nervosa. Addictive Behaviors. 1997; 22:437-446. [PubMed: 9290854] 
Bulik CM, Sullivan PF, Kendler KS. Heritability of binge-eating and broadly defined bulimia nervosa. Biological Psychiatry. 1998; 44:1210-1218. [PubMed: 9861464]

Bulik CM, Thornton LM, Root TL, Pisetsky EM, Lichtenstein P, Pedersen NL. Understanding the relation between anorexia nervosa and bulimia nervosa in a Swedish national twin sample. Biological Psychiatry. 2010; 67:71-77. [PubMed: 19828139]

Dansky BS, Brewerton TD, Kilpatrick DG. Comorbidity of bulimia nervosa and alcohol use disorders: results from the national women's study. International Journal of Eating Disorders. 2000; 27:180190. [PubMed: 10657891]

Dawe S, Loxton NJ. The role of impulsivity in the development of substance use and eating disorders. Neuroscience and Biobehavioral Reviews. 2004; 28:343-351. [PubMed: 15225976]

First, MB.; Gibbon, M. The Structured Clinical Interview for DSM-IV Axis I Disorders (SCID-I) and the Structured Clinical Interview for DSM-IV Axis II Disorders (SCID-II).. In: Hilsenroth, MJ.; Segal, DL., editors. Comprehensive Handbook of Psychological Assessment Volume 2: Personality assessment. Wiley; Hoboken: 2004. p. 134-143.

First, MB.; Spitzer, RL.; Gibbon, M.; Williams, JBW. Structured Clinical Interview for DSM-IV Axis I Disorders (SCID-I), Clinician Version. American Psychiatric Press; Washington, DC: 1997.

Furberg H, Lichtenstein P, Pedersen NL, Thornton L, Bulik CM, Lerman C, Sullivan PF. The STAGE cohort: a prospective study of tobacco use among Swedish twins. Nicotine and Tobacco Research. 2008; 10:1727-1735. [PubMed: 18988069]

Garfinkel PE, Lin E, Goering P, Spegg C, Goldbloom DD, Kennedy S, Kaplan AS, Woodside DB. Bulimia nervosa in a Canadian community sample: Prevalence and comparison of subgroups. American Journal of Psychiatry. 1995; 152:1052-1058. [PubMed: 7793442]

Heath AC, Bucholz KK, Madden PA, Dinwiddie SH, Slutske WS, Bierut LJ, Statham DJ, Dunne MP, Whitfield JB, Martin NG. Genetic and environmental contributions to alcohol dependence risk in a national twin sample: Consistency of findings in women and men. Psychological Medicine. 1997; 27:1381-1396. [PubMed: 9403910]

Herzog DB, Dorer DJ, Keel PK, Selwyn SE, Ekeblad ER, Flores AT, Greenwood DN, Burwell RA, Keller MB. Recovery and relapse in anorexia and bulimia nervosa: A 7.5-year follow-up study. Journal of the American Academy of Child and Adolescent Psychiatry. 1999; 38:829-837. [PubMed: 10405500]

Holderness CC, Brooks-Gunn J, Warren MP. Co-morbidity of eating disorders and substance abuse review of the literature. International Journal of Eating Disorders. 1994; 16:1-35. [PubMed: 7920577]

Hudson JI, Hiripi E, Pope HG Jr. Kessler RC. The prevalence and correlates of eating disorders in the National Comorbidity Survey Replication. Biological Psychiatry. 2007; 61:348-358. [PubMed: 16815322]

Kassett JA, Gershon ES, Maxwell ME, Guroff JJ, Kazuba DM, Smith AL, Brandt HA, Jimerson DC. Psychiatric disorders in the first-degree relatives of probands with bulimia nervosa. American Journal of Psychiatry. 1989; 146:1468-1471. [PubMed: 2817120]

Kendler KS, MacLean C, Neale MC, Kessler RC, Heath AC, Eaves LJ. The genetic epidemiology of bulimia nervosa. American Journal of Psychiatry. 1991; 148:1627-1637. [PubMed: 1842216]

Kendler KS, Myers J, Prescott CA. Specificity of genetic and environmental risk factors for symptoms of cannabis, cocaine, alcohol, caffeine, and nicotine dependence. Archives of General Psychiatry. 2007; 64:1313-1320. [PubMed: 17984400]

Kendler, KS.; Prescott, CA. Genes, environment, and psychopathology: Understanding the causes of psychiatric and substance abuse disorders. The Guilford Press; New York: 2006.

Kendler KS, Walters EE, Neale MC, Kessler RC, Heath AC, Eaves LJ. The structure of the genetic and environmental risk factors for six major psychiatric disorders in women: Phobia, generalized anxiety disorder, panic disorder, bulimia, major depression and alcoholism. Archives of General Psychiatry. 1995; 52:374-383. [PubMed: 7726718]

Klump KL, Burt SA. The Michigan State University Twin Registry (MSUTR): genetic, environmental and neurobiological influences on behavior across development. Twin Research and Human Genetics. 2006; 9:971-977. [PubMed: 17254439] 
Kortegaard LS, Hoerder K, Joergensen J, Gillberg C, Kyvik KO. A preliminary population-based twin study of self-reported eating disorder. Psychological Medicine. 2001; 31:361-365. [PubMed: 11232922]

Leggio L, Addolorato G, Cippitelli A, Jerlhag E, Kampov-Polevoy AB, Swift RM. Role of feedingrelated pathways in alcohol dependence: A focus on sweet preference, NPY, and ghrelin. Alcoholism, Clinical and Experimental Research. 2011; 35:194-202.

Lichtenstein P, De Faire U, Floderus B, Svartengren M, Svedberg P, Pedersen NL. The Swedish Twin Registry: A unique resource for clinical, epidemiological and genetic studies. Journal of Internal Medicine. 2002; 252:184-205. [PubMed: 12270000]

Lichtenstein P, Sullivan PF, Cnattingius S, Gatz M, Johansson S, Carlström E, Björk C, Svartengren M, Wolk A, Klareskog L, de Faire U, Schalling M, Palmgren J, Pedersen NL. The Swedish Twin Registry in the third millennium: An update. Twin Research and Human Genetics. 2006; 9:875882. [PubMed: 17254424]

Lilenfeld LR, Kaye WH, Greeno CG, Merikangas KR, Plotnicov K, Pollice C, Rao R, Strober M, Bulik CM, Nagy L. Psychiatric disorders in women with bulimia nervosa and their first-degree relatives: Effects of comorbid substance dependence. International Journal of Eating Disorders. 1997; 22:253-264. [PubMed: 9285262]

Lilenfeld LR, Kaye WH, Greeno CG, Merikangas KR, Plotnikov K, Pollice C, Rao R, Strober M, Bulik CM, Nagy L. A controlled family study of restricting anorexia and bulimia nervosa: Comorbidity in probands and disorders in first-degree relatives. Archives of General Psychiatry. 1998; 55:603-610. [PubMed: 9672050]

Little, RJA.; Rubin, DB. Statistical analysis with missing data. Wiley; New York: 1987.

Mitchell JE, Hatsukami D, Eckert ED, Pyle RL. Characteristics of 275 patients with bulimia. American Journal of Psychiatry. 1985; 142:482-485. [PubMed: 3856401]

Morley JE. The neuroendocrine control of appetite: The role of the endogenous opiates, cholecystokinin, TRH, gamma-amino-butyric-acid and the diazepam receptor. Life Sciences. 1980; 27:355-368. [PubMed: 6774182]

Neale, M.; Boker, S.; Xie, G.; Maes, H. Mx: Statistical Modeling. 5th ed.. Medical College of Virginia, Department of Psychiatry; Richmond, Virginia: 2001.

Neale, M.; Cardon, L. Methodology for the Study of Twins and Families. Kluwer Academic Publisher Group; Dordrecht, the Netherlands: 1992.

Pereyra F, Jia X, McLaren PJ, Telenti A, de Bakker PI, Walker BD, Ripke S, Brumme CJ, Pulit SL, Carrington M, Kadie CM, Carlson JM, Heckerman D, Graham RR, Plenge RM, Deeks SG, Gianniny L, Crawford G, Sullivan J, Gonzalez E, Davies L, Camargo A, Moore JM, Beattie N, Gupta S, Crenshaw A, Burtt NP, Guiducci C, Gupta N, Gao X, Qi Y, Yuki Y, Piechocka-Trocha A, Cutrell E, Rosenberg R, Moss KL, Lemay P, O'Leary J, Schaefer T, Verma P, Toth I, Block B, Baker B, Rothchild A, Lian J, Proudfoot J, Alvino DM, Vine S, Addo MM, Allen TM, Altfeld M, Henn MR, Le Gall S, Streeck H, Haas DW, Kuritzkes DR, Robbins GK, Shafer RW, Gulick RM, Shikuma CM, Haubrich R, Riddler S, Sax PE, Daar ES, Ribaudo HJ, Agan B, Agarwal S, Ahern RL, Allen BL, Altidor S, Altschuler EL, Ambardar S, Anastos K, Anderson B, Anderson V, Andrady U, Antoniskis D, Bangsberg D, Barbaro D, Barrie W, Bartczak J, Barton S, Basden P, Basgoz N, Bazner S, Bellos NC, Benson AM, Berger J, Bernard NF, Bernard AM, Birch C, Bodner SJ, Bolan RK, Boudreaux ET, Bradley M, Braun JF, Brndjar JE, Brown SJ, Brown K, Brown ST, Burack J, Bush LM, Cafaro V, Campbell O, Campbell J, Carlson RH, Carmichael JK, Casey KK, Cavacuiti C, Celestin G, Chambers ST, Chez N, Chirch LM, Cimoch PJ, Cohen D, Cohn LE, Conway B, Cooper DA, Cornelson B, Cox DT, Cristofano MV, Cuchural G Jr. Czartoski JL, Dahman JM, Daly JS, Davis BT, Davis K, Davod SM, DeJesus E, Dietz CA, Dunham E, Dunn ME, Ellerin TB, Eron JJ, Fangman JJ, Farel CE, Ferlazzo H, Fidler S, FleenorFord A, Frankel R, Freedberg KA, French NK, Fuchs JD, Fuller JD, Gaberman J, Gallant JE, Gandhi RT, Garcia E, Garmon D, Gathe JC Jr. Gaultier CR, Gebre W, Gilman FD, Gilson I, Goepfert PA, Gottlieb MS, Goulston C, Groger RK, Gurley TD, Haber S, Hardwicke R, Hardy WD, Harrigan PR, Hawkins TN, Heath S, Hecht FM, Henry WK, Hladek M, Hoffman RP, Horton JM, Hsu RK, Huhn GD, Hunt P, Hupert MJ, Illeman ML, Jaeger H, Jellinger RM, John M, Johnson JA, Johnson KL, Johnson H, Johnson K, Joly J, Jordan WC, Kauffman CA, Khanlou H, Killian RK, Kim A,Y, Kim DD, Kinder CA, Kirchner JT, Kogelman L, Kojic EM, Korthuis PT, 
Kurisu W, Kwon DS, LaMar M, Lampiris H, Lanzafame M, Lederman MM, Lee DM, Lee JM, Lee MJ, Lee ET, Lemoine J, Levy JA, Llibre JM, Liguori MA, Little SJ, Liu AY, Lopez AJ, Loutfy MR, Loy D, Mohammed DY, Man A, Mansour MK, Marconi VC, Markowitz M, Marques R, Martin JN, Martin HL Jr. Mayer KH, McElrath MJ, McGhee TA, McGovern BH, McGowan K, McIntyre D, Mcleod GX, Menezes P, Mesa G, Metroka CE, Meyer-Olson D, Miller AO, Montgomery K, Mounzer KC, Nagami EH, Nagin I, Nahass RG, Nelson MO, Nielsen C, Norene DL, O'Connor DH, Ojikutu BO, Okulicz J, Oladehin OO, Oldfield EC 3rd. Olender SA, Ostrowski M, Owen WF Jr. Pae E, Parsonnet J, Pavlatos AM, Perlmutter AM, Pierce MN, Pincus JM, Pisani L, Price LJ, Proia L, Prokesch RC, Pujet HC, Ramgopal M, Rathod A, Rausch M, Ravishankar J, Rhame FS, Richards CS, Richman DD, Rodes B, Rodriguez M, Rose RC 3rd. Rosenberg ES, Rosenthal D, Ross PE, Rubin DS, Rumbaugh E, Saenz L, Salvaggio MR, Sanchez WC, Sanjana VM, Santiago S, Schmidt W, Schuitemaker H, Sestak PM, Shalit P, Shay W, Shirvani VN, Silebi VI, Sizemore JM Jr. Skolnik PR, Sokol-Anderson M, Sosman JM, Stabile P, Stapleton JT, Starrett S, Stein F, Stellbrink HJ, Sterman FL, Stone VE, Stone DR, Tambussi G, Taplitz RA, Tedaldi EM, Telenti A, Theisen W, Torres R, Tosiello L, Tremblay C, Tribble MA, Trinh PD, Tsao A, Ueda P, Vaccaro A, Valadas E, Vanig TJ, Vecino I, Vega VM, Veikley W, Wade BH, Walworth C, Wanidworanun C, Ward DJ, Warner DA, Weber RD, Webster D, Weis S, Wheeler DA, White DJ, Wilkins E, Winston A, Wlodaver CG, van't Wout A, Wright DP, Yang OO, Yurdin DL, Zabukovic BW, Zachary KC, Zeeman B, Zhao M. The major genetic determinants of HIV-1 control affect HLA class I peptide presentation. Science. 2010; 330:1551-1557. [PubMed: 21051598]

Pyle RL, Mitchell JE, Eckert ED. Bulimia: A report of 34 cases. Journal of Clinical Psychiatry. 1981; 42:60-64. [PubMed: 6936397]

Root TL, Pisetsky EM, Thornton L, Lichtenstein P, Pedersen NL, Bulik CM. Patterns of co-morbidity of eating disorders and substance use in Swedish females. Psychological Medicine. 2010; 40:105115. [PubMed: 19379530]

Sartor CE, McCutcheon VV, Pommer NE, Nelson EC, Grant JD, Duncan AE, Waldron M, Bucholz KK, Madden PA, Heath AC. Common genetic and environmental contributions to post-traumatic stress disorder and alcohol dependence in young women. Psychological Medicine. 2011; 41:14971505. [PubMed: 21054919]

Slane JD, Burt SA, Klump KL. Bulimic Behaviors and alcohol use: Shared genetic influences. Behavior Genetics. 2012; 42:603-613. [PubMed: 22302528]

Sullivan PF, Bulik CM, Kendler KS. The epidemiology and classification of bulimia nervosa. Psychological Medicine. 1998; 28:599-610. [PubMed: 9626716]

Tourangeau, R.; Smith, T. Collecting Sensitive Information with Different Modes of Data Collection.. In: Couper, MP., editor. Computer Assisted Survey Information Collection. Wiley; New York: 1998. p. 455-474.

Trace SE, Thornton LM, Root TL, Mazzeo SE, Lichtenstein P, Pedersen NL, Bulik CM. Effects of reducing the frequency and duration criteria for binge eating on lifetime prevalence of bulimia nervosa and binge eating disorder: implications for DSM-5. International Journal of Eating Disorders. 2012; 45:531-536. [PubMed: 21882218]

Volkow ND, Wise RA. How can drug addiction help us understand obesity? Nature Neuroscience. 2005; 8:555-560.

Wilson TG, Sysko RS. Frequency of binge eating episodes in bulimia nervosa and binge eating disorder: Diagnostic considerations. Internation Journal of Eating Disorders. 2009; 42:603-610.

Wade TD, Bergin JL, Tiggemann M, Bulik CM, Fairburn CG. Prevalence and long- term course of lifetime eating disorders in an adult Australian twin cohort. Australia and New Zealand Journal of Psychiatry. 2006; 40:121-128.

Wade TD, Bulik CM, Prescott CA, Kendler KS. Sex influences on shared risk factors for bulimia nervosa and other psychiatric disorders. Archives of General Psychiatry. 2004; 61:251-256. [PubMed: 14993112]

Walters EE, Neale MC, Eaves LJ, Heath AC, Kessler RC, Kendler KS. Bulimia nervosa and major depression: a study of common genetic and environmental factors. Psychological Medicine. 1992; 22:617-622. [PubMed: 1410087] 
Table 1

Tetrachoric correlation coefficients (r) and 95\% confidence intervals (95\% CI) for bulimia nervosa and alcohol use disorder.

\begin{tabular}{|c|c|c|c|c|}
\hline & & & MZ & DZ \\
\hline \multirow{6}{*}{ Within Trait } & \multirow{3}{*}{ BN } & $\mathrm{N}^{*}$ & 3768 & 2634 \\
\hline & & Concordant/Discordant Pairs ${ }^{* *}$ & $11 / 63$ & $0 / 55$ \\
\hline & & $\mathrm{r}(95 \% \mathrm{CI})$ & $0.63(0.47 ; 0.79)$ & $-0.02(-0.47 ; 0.45)$ \\
\hline & \multirow{3}{*}{ AUD } & $\mathrm{N}^{*}$ & 4024 & 2860 \\
\hline & & Concordant/Discordant Pairs ${ }^{*}$ & $55 / 175$ & $20 / 141$ \\
\hline & & $\mathrm{r}(95 \% \mathrm{CI})$ & $0.65(0.57 ; 0.73)$ & $0.42(0.27 ; .056)$ \\
\hline \multirow{6}{*}{ Cross Trait } & \multirow{3}{*}{ Within Twin } & $\mathrm{N}^{*}$ & 3942 & 2782 \\
\hline & & Concordant/Discordant Diagnoses ${ }^{* *}$ & $20 / 339$ & $10 / 224$ \\
\hline & & $\mathrm{r}(95 \% \mathrm{CI})$ & $0.30(0.18 ; 0.42)$ & $0.24(0.08 ; 0.40)$ \\
\hline & \multirow{3}{*}{ Cross Twin } & $\mathrm{N}^{*}$ & 3882 & 2741 \\
\hline & & Concordant/Discordant Pairs ${ }^{*}$ & $11 / 346$ & $4 / 224$ \\
\hline & & $\mathrm{r}(95 \% \mathrm{CI})$ & $0.14(0.00 ; 0.28)$ & $0.02(-0.21 ; 0.23)$ \\
\hline
\end{tabular}

Note. $\mathrm{N}^{*}=$ number of individuals used in the calculation

number of concordant affected pairs and number of discordant pairs used in the calculation

**

number of twins with both BN and AUD (concordant) and number of twins with only one diagnosis, BN or AUD (discordant). Within trait ("intraclass correlations") correlations reflect the correlation of bulimia nervosa and alcohol use disorder between members of twin pairs by zygosity group. Cross-trait, within twin correlations reflect the correlation between bulimia nervosa and alcohol use disorder within individuals. Cross-trait, cross-twin correlations reflect the correlations of bulimia nervosa in one twin with alcohol use disorder in the co-twin by zygosity groups 
Table 2

Bivariate model fit statistics for bulimia nervosa and alcohol use disorder.

\begin{tabular}{c|c|c|c|c|c|c}
\hline Model No. & Model & $\mathbf{- 2 l n L}$ & df & $\mathbf{X}^{\mathbf{2}}$ diff (df) & p-value & AIC \\
\hline I & ACE-ACE, $\mathrm{r}_{\mathrm{a}} \mathrm{r}_{\mathrm{c}} \mathrm{r}_{\mathrm{e}}$, & 4858.60 & 14629 & --- & -- & -24399.40 \\
\hline II & ACE-ACE, $\mathrm{r}_{\mathrm{c}} \mathrm{r}_{\mathrm{e}}$ & 4860.24 & 14630 & $1.64(1)$ & .200 & -24399.76 \\
\hline III & ACE-ACE, $\mathrm{r}_{\mathrm{a}} \mathrm{r}_{\mathrm{e}}$ & 4858.66 & 14630 & $0.07(1)$ & .799 & -24401.34 \\
\hline IV & AE-AE, $\mathrm{r}_{\mathrm{a}} \mathrm{r}_{\mathrm{e}}(\mathrm{best}$ fit) & $\mathbf{4 8 5 9 . 2 4}$ & $\mathbf{1 4 6 3 2}$ & $\mathbf{0 . 6 5}(\mathbf{3})$ & $\mathbf{. 8 8 6}$ & $\mathbf{- 2 4 4 0 4 . 7 6}$ \\
\hline V & AE-AE, $\mathrm{r}_{\mathrm{a}}$ & 4865.45 & 14633 & $6.86(4)$ & .144 & -24400.55 \\
\hline VI & AE-AE, $\mathrm{r}_{\mathrm{e}}$ & 4863.59 & 14633 & $4.99(4)$ & .288 & -24402.41 \\
\hline VII & CE-CE, $\mathrm{r}_{\mathrm{c}} \mathrm{r}_{\mathrm{e}}$ & 4875.09 & 14632 & $16.49(3)$ & .001 & -24388.91 \\
\hline VIII & E-E, $\mathrm{r}_{\mathrm{e}}$ & 5031.99 & 14635 & $173.39(6)$ & .000 & -24238.01 \\
\hline
\end{tabular}

Note AIC = Akiake's Information Criterion (Akaike, 1987); $-2 \operatorname{lnL}=-2 \log$ likelihood; $\mathrm{df}=$ degrees of freedom; $\mathrm{ACE}=$ additive genetic, common environment, and unique environmental effects model; $\mathrm{AE}=$ additive genetic and unique environmental effects model; $\mathrm{CE}=$ common and unique environmental effects model; $\mathrm{E}=$ unique environmental effects model; $\mathrm{r}_{\mathrm{a}}=$ genetic correlation between bulimia nervosa and alcohol use disorder; $r_{c}=$ common environmental correlation between bulimia nervosa and alcohol use disorder; $r_{e}=$ unique environmental correlation between bulimia nervosa and alcohol use disorder. 


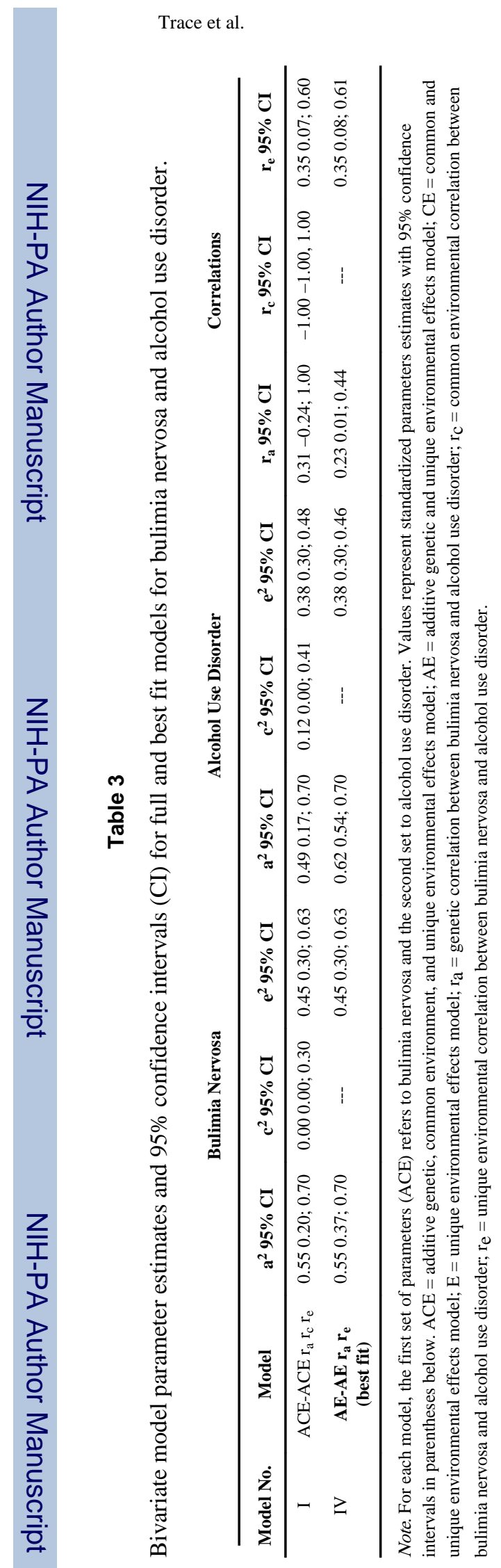

Psychiatry Res. Author manuscript; available in PMC 2014 August 15. 